\title{
Keterlibatan Mahasiswa dan Akademisi dalam Pengabdian Masyarakat Menghadapi Pandemi Covid-19
}

\author{
Seri Hartati*1, Amir Syamsuadi' ${ }^{2}$, luluk Elvitaria ${ }^{3}$ \\ 1,2,3Program Studi Ilmu Pemerintahan, Fakultas Ilmu Sosial dan Politik, Universitas abdurrab \\ *e-mail: seri.hartati@univrab.ac.id ${ }^{1}$
}

\begin{abstract}
Coronavirus (COVID-19) is an infectious disease caused by a new version of the coronavirus that was discovered at the end of 2019. Most of the disorders experienced by individuals infected with the COVID-19 virus will experience respiratory disease and most of them recover without requiring special treatment. Indonesia is currently hit by the Covid-19 pandemic. Various policies in prevention efforts have been carried out by the government, which have an impact many aspects of society. In Pekanbaru specially needs a lot of information related to Covid 19. Through Community Service in Simpang Tiga Village, Bukit Raya District, they can provide aid of information or other social aid which is a synergy of students and academics during the Covid 19 Pandemic, of course by following health protocol procedures. The results of this service are expected to assist the government and society as an effort to break the chain of spreading covid-19.
\end{abstract}

Keywords: covid-19, Students, Academics, Engagement, Community Service

\begin{abstract}
Abstrak
Coronavirus (COVID-19) adalah penyakit menular yang disebabkan oleh coronavirus versi baru yang ditemukan pada akhir 2019 lalu. Sebagian besar gangguan yang dialami oleh individu yang terinfeksi COVID19 akan mengalami penyakit pernapasan ringan hingga sedang dan sembuh tanpa memerlukan perawatan khusus. Dampak yang lebih besar hingga kematian, data hingga April 2021 menunjukkan dari 136 juta yang terinfeksi, 77,6 juta sembuh sementara meninggal dunia sebesar2,94 juta. Indonesia merupakan satu negara yang sedang dilanda bencana pandemi Covid-19. Berbagai kebijakan dalam upaya pencegahan telah dilakukan oleh pemerintah, yang berdampak pada banyak aspek di masyarakat. Masyarakat pekanbaru khususnya saat ini memerlukan banyak informasi terkait Covid 19. Melalui Pengabdian Pada Masyarakat di Kelurahan Simpang Tiga Kecamatan Bukit Raya ini dapat memberikan bantuan berupa informasi ataupun bantuan sosial lainnya yang merupakan sinergi mahasiswa, akademisi dan masyarakat di masa Pandemi Covid 19 dalam bentuk sosialisasi protokol kesehatan, edukasi kesehatan, pembagian masker, alat pencuci tangan, sanitizer, pembagian sembako dengan mengikuti prosedur protokol kesehatan. Adapun hasil pengabdian ini diharapkan dapat Membantu pemerintah dan masyarakat dalam upaya untuk memutus rantai penyebaran covid-19
\end{abstract}

Kata kunci: Covid-19, Mahasiswa, Akademisi, Keterlibatan, Pengabdian Masyarakat

\section{PENDAHULUAN}

Sejak ditemukannya virus corona pada tahun 2019, dunia mengalami kegoncangan dalam menghadapi penyakit tersebut. Dalam epidemi berkelanjutan terhadap Covid-19, belum semua aspek ditangani, meskipun masyarakat global di seluruh dunia dihadapkan dengan berbagai kebijakan menghadapi epidemi tersebut (Pradana, Casman, \& Aini, 2020). Dalam perkembangannya, kasus Covid-19 dinyatakan bukan lagi epidemi tetapi sebagai kasus pandemik, sehingga diperlukan kerjasama dan koordinasi dengan berbagai pihak untuk mengatasi masalah tersebut.

Berdasarkan Keputusan Menkes RI No.HK.01.07/MENKES/238/2020 dinyatakan bahwa sejak 31 Desember 2019 mulai tersebar informasi mengenai penyakit Wuhan Pneumonia yang disebabkan oleh Covid-19 (Agustino, 2020). Covid-19 telah dinyatakan oleh WHO sebagai Kedaruratan Kesehatan Masyarakat yang Meresahkan Dunia (KKMMD)/ Public Health Emergency of International Concern (PHEIC)/Pandemi, di mana penularannya sangat cepat pada manusia serta angka kematian yang cukup tinggi. Indonesia termasuk dalam negara dengan kasus Covid19 tinggi, data di beberapa daerah menunjukkan adanya peningkatan penderita bahkan berujung pada kematian (Saputra \& Putra, 2020). Sehingga dalam penanganan kasus tersebut perlu 
manajemen komunikasi krisis yang tepat. Di sisi lain dalam Peraturan Menteri Komunikasi dan Informasi RI No. 8/2019, tentang Manajemen Komunikasi Krisis, disebutkan pada pasal 17 (3) bahwa dalam pengelolaan manajemen komunikasi krisis dilakukan koordinasi dengan berbagai pihak terkait (Bahri \& Arafah, 2020).

Dalam rangka mengatasi kasus Covid-19, urgensi kemandirian dan inovasi dari masyarakat menjadi hal yang penting saai ini (Rahmi, Ismanto, \& Fathoni, 2020). Pemberdayaan masyarakat diperlukan agar penanganan pandemi Covid-19 mengalami percepatan signifikan (Sunuantari, 2020). Pemberdayaan masyarakat merupakan suatu usaha untuk meningkatkan martabat masyarakat agar mereka dapat keluar dari kemiskinan dan keterbelakangan (Laksono, 2018). Keterlibatan berbagai komunitas dalam masyarakat akan lebih berhasil karena komunitaskomunitas tersebut dapat menggunakan berbagai cara untuk terlibat di dalamnya (Walzer \& Hamm, 2012). Untuk itulah maka dalam rangka mendorong keberdayaan masyarakat perlu melibatkan berbagai pihak baik mahasiswa ataupun akademisi sehingga aktivitas lebih maksimal (Sampurno, Kusumandyoko, \& Islam, 2020). Sebagai suatu lembaga universitas abdurrab merupakan lembaga pendidikan yang berkewajiban melaksanakan dharma perguruan tinggi, salah satunya dengan mengadakan KKN (Herlan et al., 2020).

Berdasarkan hasil survei yang dilakukan oleh LPPM dan juga hasil koordinasi dengan pihak pemerintah setempat maka KKN pada tahun 2020 ini diselenggarakan diwilayah yang ada di Provinsi Riau dengan Skema pelaksanaan Kuliah Kerja Nyata yakni:"KKN Terintegrasi"dan "KKN Balek Kampung"dengan yang ditimbang karena kondisi pandemi Covid-19. Melalui program ini memungkinkan terjadinya interaksi individu dalam berbagai peran dimana sebelumnya masih kurang kesadaran dalam perlindungan diri dari covid, tingkat kesadaran masyarakat Kelurahan Simpang Tiga masih terlihat abai dalam mengikuti protokol kesehatan maka dari itu diperlukan tidak hanya peran formal dalam lembaga namun juga harus ada peran dari seluruh elemen masyarakat. Keterlibatan dosen dan mahasiswa memberikan kesempatan setiap orang untuk berperan aktif dalam pengabdian masyrakat khususnya pada masa pandemi covid 19 (Herlan et al., 2020).

\section{METODE}

Kegiatan Pengabdian Masyarakat ini dilakukan di Kelurahan Simpang Tiga Kecamatan Bukit Raya dengan mengususng Program KKN Abdurrab Balek Kampung. Program KKN Balek Kampung ini merupakan program KKN yang terkondisikan karena Covid 19 dimana seharusnya mahasiswa harus terjun ke daerah tertentu untuk melakukkan KKN, pada saat kondisi covid ini Universitas memberikan sebuah kelonggaran dimana mahasiswa yang masih berada diwilayah masing - masing dalam artian kampung masing - masing masih dapat melakukan KKN dan tentu saja mengikuti prosedur yang berlaku. Keterlibatan mahasiswa dan dosen dalam kegiatan ini mengikuti protokol kesehatan new normal dimasa semua kegiatan yagn bisa dilakukan menggunakan Teknologi Informasi dimaksimalkan, sementara kegiatan yang harus ke lapangan tetap mengikuti prosedur dengan menggunakan masker dan selalu cuci tangan saat memasuki wilayah tertutup. Mahasiswa dan dosen membuat program dengan tema tata kelola covid 19. Melaui sinergi antara mahasiswa, dosen dan masyarakat di kelurahan Simpang Tiga diharapkan dapat membantu percepatan penanganan tata kelola covid 19 di kelurahan tersebut. Program dilaksanakan selama tiga minggu. Dimana minggu pertama perencaan program dan analisa masalah di lapangan, minggu kedua pelaksanaan program kegiatan dan minggu ketiga pelaksaan kegiatan sekaligus pemberian bantuan kepada masyarakat kurang mampu berupa sembako. Pelaksaan KKN abdurrab ini tidak bisa berlangsung lama dikarenakan kondisi new normal.

\section{HASIL DAN PEMBAHASAN}

Pengabdian kepada masyarakat ini dilakukan di kelurahan Simpang Tiga Kecamatan Bukit Raya Provinsi Riau Pekanbaru. Kegiatan pengabdian ini dilaksanakan dengan mengusung konsep 
kolaborasi terutama karena situasi dan kondisi pada masa pandemi ini berlangsung. Melalui Program KKN Univrab "Balek Kampung" keterlibatan akademisi dan mahasiswa diharapkan dapat mengatasi persoalan yang ada dimasyarakat khususnya menghadapi pandemi Covid - 19.

Pemerintahan Kecamatan Bukit Raya sangat antusias dalam membantu kegiatan KKN ini dengan melibatkan seluruh staf dalam struktur pemerintahan kecamatan dan juga dibantu dengan BABINSA TNI AD dalam pendistibusian sembako. Keterlibatan seluruh staf yang menunjukan seluruh kegiatan organisasi agar setiap rencana yang dilakukan dapat dicapai semaksimal mungkin untuk memperoleh hasil yang sangat membanggakan dan memuaskan (Harirah \& Rizaldi, 2020). Sinergi antara Pemeintahan setempat dan seluruh elemen masyarakat sangat diperlukan dalam menghadapi bencana covid 19 ini (Telaumbanua, 2020). Dalam menghadapi pandemi covid 19, masyarakat pekanbaru khususnya Kelurahan simpang Tiga telah banyak melakukan usaha melalui penyediaan tempat cuci tangan, sosialisasi penggunaan masker dan jaga jarak sesuai dengan anjuran pemerintah mengikuti prosedur kesehatan.

Untuk mendukung sosialisasi pemerintah menghadapi Covid 19 ini, KKN Univrab mengusung Program Kerja Pengabdian Masyarakat dengan melibatkan seluruh elemen masyarakat. Berikut program kerja KKN Univrab :

Tabel 1. Program Kerja Fisik

\begin{tabular}{|c|c|c|c|}
\hline No & Program Kerja & Kegiatan & Tujuan \\
\hline 1 & $\begin{array}{l}\text { Himbauan protokol } \\
\text { kesehatan dan } \\
\text { adaptasi kebiasaan } \\
\text { baru }\end{array}$ & $\begin{array}{lr}\text { Memberikan } & \text { himbauan } \\
\text { protokol kesehatan dan } \\
\text { adaptasi r kebiasaan } \\
\text { baru r saat } \\
\text { melaksanakan }\end{array}$ & \begin{tabular}{l}
\multicolumn{2}{l}{ Meningkatkan } \\
kesadaran masyarakat \\
terkait \\
kesehatan menjaga \\
menyelamatkan diri \\
sendiri maupun orang \\
lain dalam melakukan \\
aktivitas sehari-hari \\
dengan cara selalu \\
menggunakan masker \\
dan selalu mencuci \\
tangan
\end{tabular} \\
\hline 2 & $\begin{array}{l}\text { Pemasangan skat } \\
\text { pembatas di depan } \\
\text { meja pelayanan } \\
\text { administrasi di } \\
\text { depan kantor lurah } \\
\text { simpang tiga }\end{array}$ & \begin{tabular}{lr} 
Menyebarkan & brosur \\
terkait & kepad \\
amasyarakat & saat \\
melaksanakan & Kukerta \\
\multicolumn{2}{l}{ Balek Kampung }
\end{tabular} & \begin{tabular}{lr} 
Untuk mengurangi & \multicolumn{2}{c}{ mak } \\
adanya kontak fisik \\
secara langsung serta \\
Meningkat kesadaran \\
masyarakat \\
menajaga kesehatan \\
fisik agar tidak \\
terjangkit covid-19
\end{tabular} \\
\hline 3 & \begin{tabular}{l}
\multicolumn{2}{l}{ Bekerjasama } \\
antara mahasiswa \\
KKN Univrab kel- \\
$25 \quad$ dengan \\
BABINSA TNI-AD \\
untuk membagikan \\
masker
\end{tabular} & $\begin{array}{lr}\text { Memberikan } & \text { secara } \\
\text { gratis } & \text { kepada } \\
\text { masyarakat } & \text { Kel. } \\
\text { Simpang tiga } & \text { terutama } \\
\text { yang } & \text { sedang } \\
\text { beraktivitas } & \text { tidak } \\
\text { menggunakan masker } \\
\text { dan yang sedang makan } \\
\text { di rumah makan } \\
\text { terdekat dari posko } \\
\text { relawan pencegahan } \\
\text { covid-19 }\end{array}$ & $\begin{array}{lr}\text { Untuk meningkatkan } \\
\text { kesadaran } & \text { kepada } \\
\text { masyarakat } & \text { guna } \\
\text { menjaga kesehatan fisik } \\
\text { serta } & \text { untuk } \\
\text { mendapatkan } & \\
\text { dukungan } & \text { dari } \\
\text { masyarakat } & \text { terkait } \\
\text { kegiatan yang } & \text { kami } \\
\text { laksanakan } & \end{array}$ \\
\hline
\end{tabular}




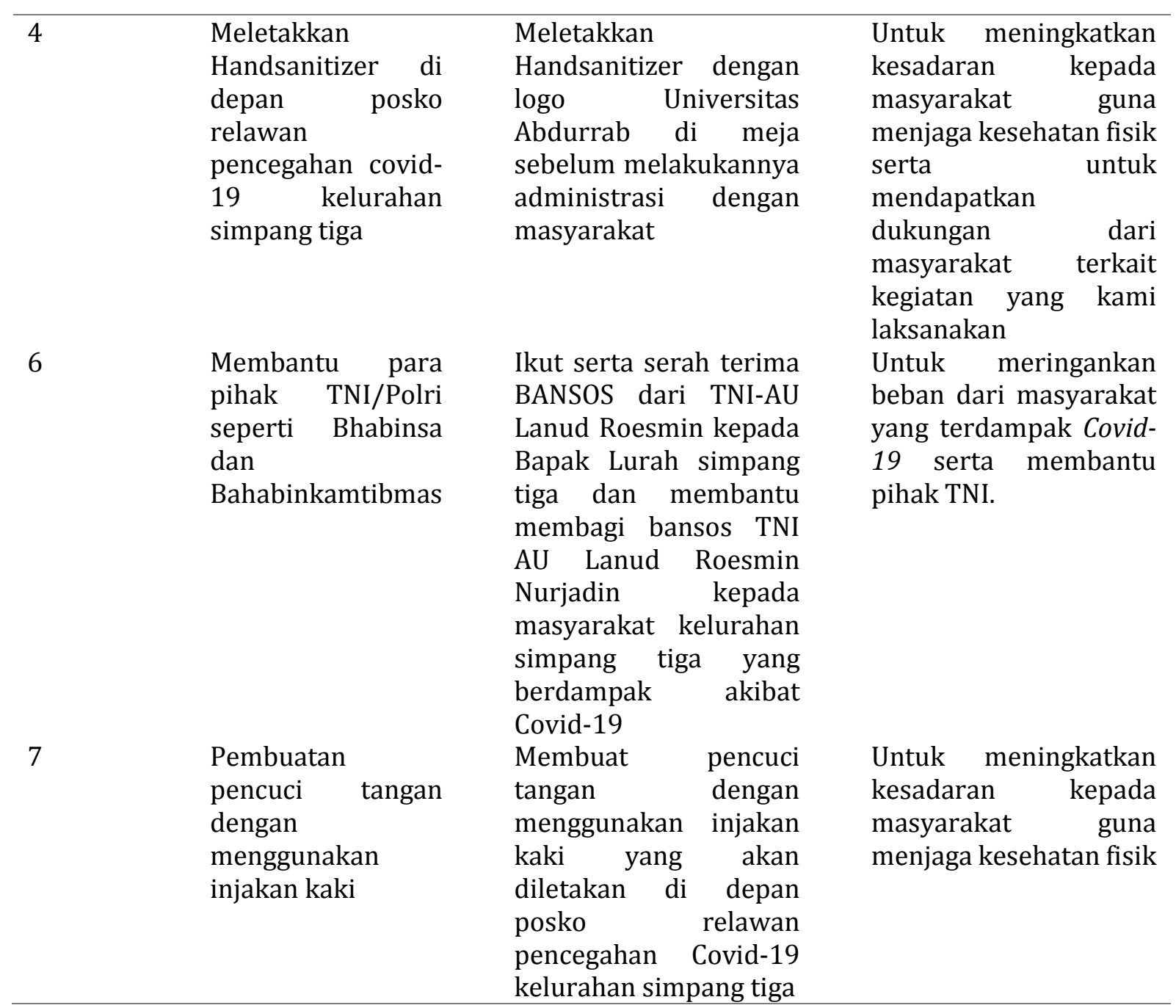

Tabel 2. Program Kerja Non Fisik

\begin{tabular}{|c|c|c|c|}
\hline & Program Kerja & Kegiatan & Tujuan \\
\hline 1 & 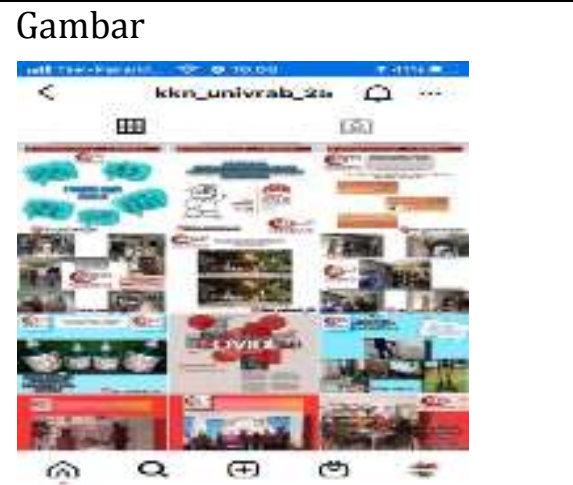 & $\begin{array}{l}\text { Membuat gambar design } \\
\text { yang berisikan edukasi dan } \\
\text { aktifitas yang dilakukan } \\
\text { selama KKN dikelurahan } \\
\text { simpang tiga melalui sosial } \\
\text { media KKN Universitas } \\
\text { Abdurrab Kelompok 25 } \\
\text { melalui media instagram : } \\
\text { @kkn_univrab_25 }\end{array}$ & $\begin{array}{l}\text { Meningkatkan } \\
\text { kreativitas mahasiswa } \\
\text { yang melakukan } \\
\text { Kukerta dalam } \\
\text { mengedukasi } \\
\text { masyarakat }\end{array}$ \\
\hline 2 & $\begin{array}{l}\text { Blog } \\
\text { https://www.pekanbaruinfo.com } \\
\text { /2020/09/kukerta-kelompok- } \\
\text { 25-universitas.html?m=1 }\end{array}$ & $\begin{array}{l}\text { Membuat blog dan } \\
\text { memberikan informasi } \\
\text { yang bermanfaat bagi } \\
\text { pembaca di dunia maya. }\end{array}$ & $\begin{array}{l}\text { Meningkatkan } \\
\text { kreativitas mahasiswa } \\
\text { yang melakukan } \\
\text { Kukerta dalam } \\
\text { mengedukasi } \\
\text { masyarakat. }\end{array}$ \\
\hline
\end{tabular}


Prgram tersebut mendapat perhatian yang baik dari masyarakat dan juga pihak kelurahan Simpang Tiga. Berdasarkan letak geografis Kelurahan Simpang Tiga mempunyai letak yang sangat strategis dan memiliki sarana dan pra sarana yang memadai juga prospek untuk lebih berkembang. Namun, pertumbuhan ekonomi yang kurang merata padahal sudah berada di tengah kota, akan tetapi masih banyak masyarakat yang kurang mampu. Ditambah dampak pandemi covid-19 ini semakin banyak masyarakat yang terkena dampaknya mulai dari diberhentikan ditempat kerja, pengurangan hak kerja, bahkan dari segi ekonomi kesulitan dalam memenuhi kebutuhan sehari-hari (Oktaviyani, Aprilia, Sari, Rohmah, \& Saputro, 2020). Meskipun Pemerintah Kota Pekanbaru sudah berusaha semaksimal mungkin untuk mencari solusi memperbaiki ekonomi di saat kondisi pandemi ini, namun hal tersebut masih belum bisa terselesaikan karena begitu padatnya masyarakat Kelurahan Simpanga tiga yang harus dibantu perekonomiannya. Maka dari itu Bantuan sosial diberikan melalui program pengabdian masyarakat ini agar dapat membantu memberikan solusi. Berikut beberapa foto kegiatan:

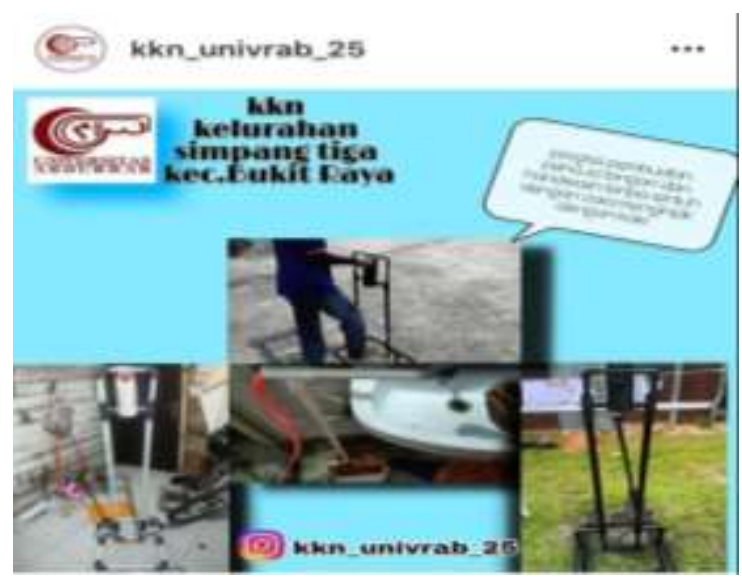

(a)

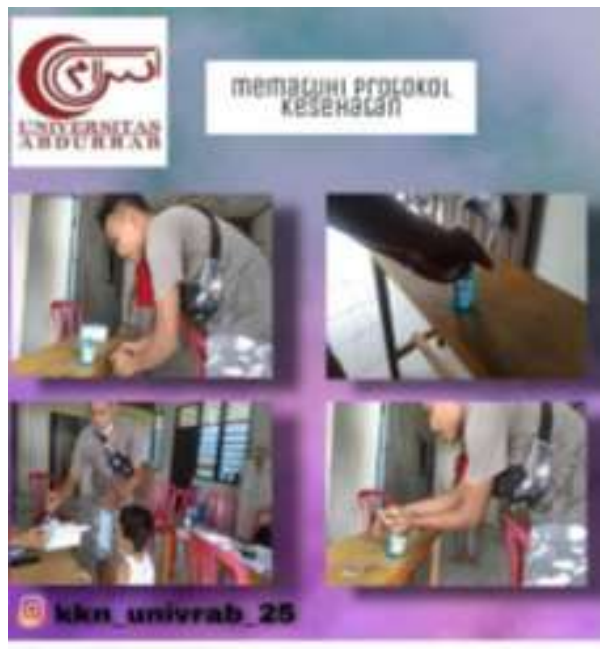

(b)

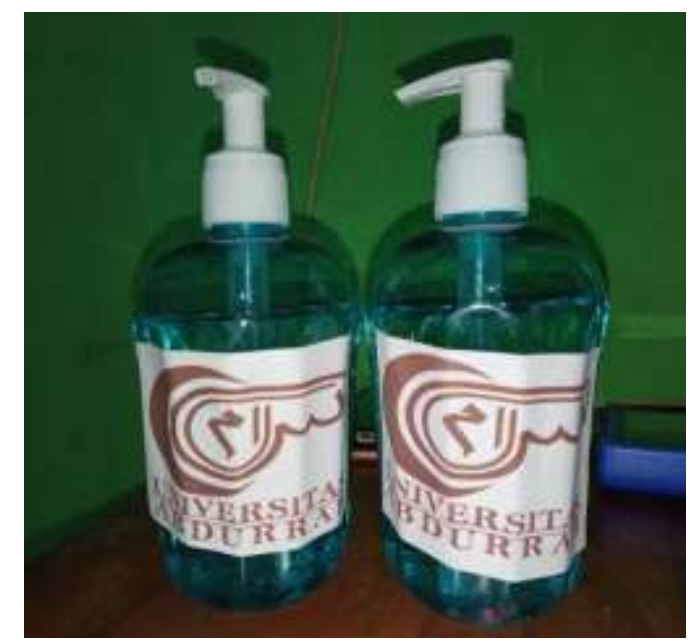

(c)

Gambar 2. (a) Alat Pencuci Tangan (b) Pembagian Masker dan Sanitizer (c) Hand Sanitizer Buatan Abdurrab 


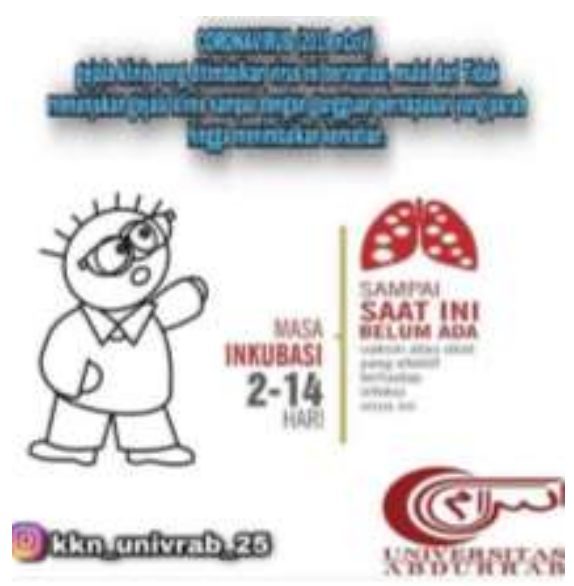

(d)

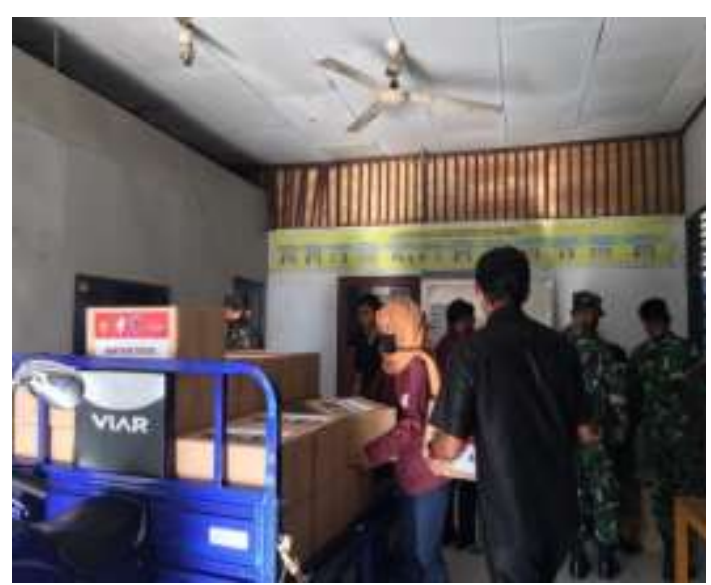

(f)

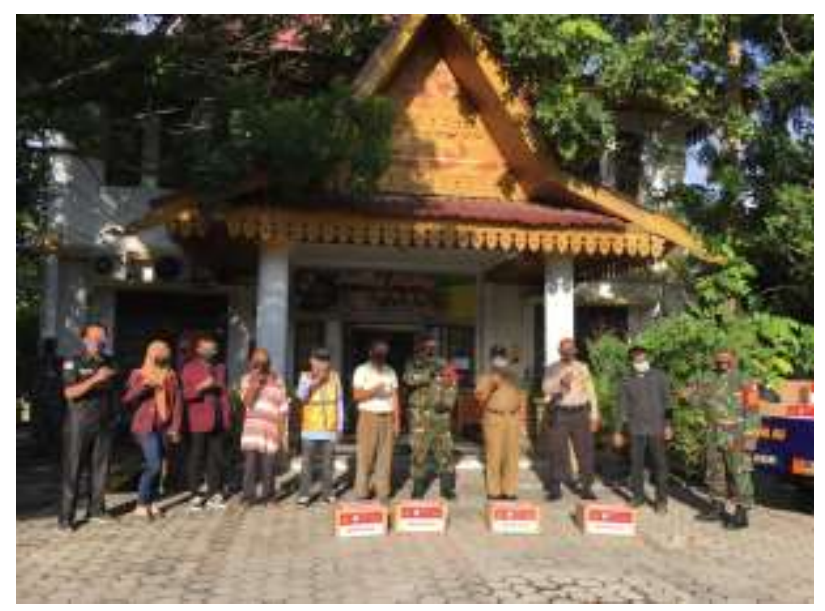

(e)

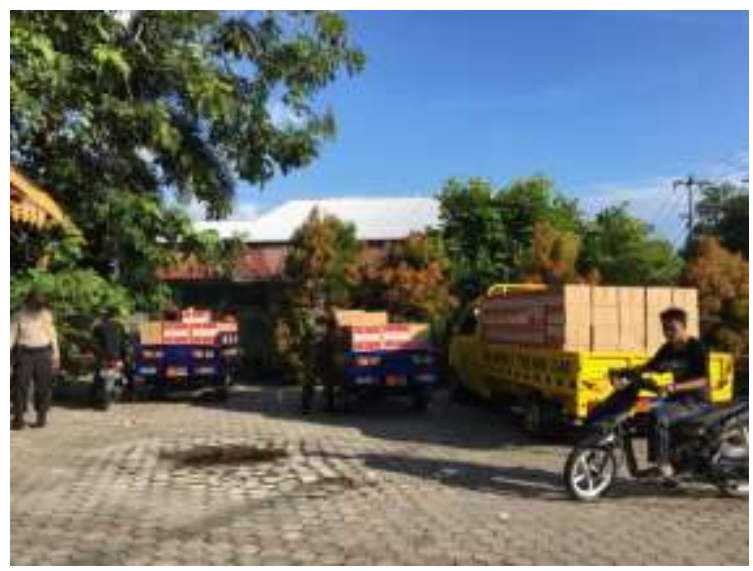

(g)

Gambar 3. (d) Flyer edukasi Covid 19 (e) denganTNI AD (f) Pembagian Sembako

(g) Distribusi Sembako

Pelaksanaan kegiatan ini dikarenakan adanya kurang kesadaran masyarakat dan minimnya fasilitas Kesehatan Kota Pekanbaru terutama di kelurahan simpangtiga, maka kelompok 25 berinisiatif untuk membuat atau meletakkan alat pencuci tangan (gambar a) dengan cara menginjakkan kaki tanpa menyentuhnya dengan tangan yang membuat masyarakat menarik untuk selalu mencuci tangan, selain itu Bpak Lurah simpangtiga dengan para karyawan sangat mendukung penuh kegiatan Kukerta Abdurrab ini dan juga mengucapkan terima kasih kepada mahasiswa Kukerta Universitas Abdurrab karena telah turut membantu dalam membangkitkan kesadaran masyarakat Kota Pekanbaru terutama di wilayah Kelurahan Simpangtiga untuk selalu mengikuti arahan dari protokol kesehatan. Untuk kegiatan pembagian masker dilakukan dengan pembagian di sekitar Kelurahan Simpangtiga dengan langsung didampingi oleh Bapak lurah, Ketua Posko relawan covid-19, para bapak TNI dan POLRI agar pembagian maskernya pun dapat terlaksana dengan baik.

\section{KESIMPULAN}

Melalui Program Pengabdian Masyarakat ini dapat dirasakan manfaatnya bagi masyarakat. KKN Univrab 2020 di Kelurahan Simpangtiga yang telah dijalankan antar lain meliputi program sosialisasi protokol kesehatan, pembagian masker, alat pencuci tangan, 
sanitizer dan pembagian sembako. Program ini telah berhasil membuktikan keterlibatan mahasiswa dan akademisi memberikan efek signifikan dalam menghadapi pandemi covid 19. Mahasiswa dan akademisi ikut serta membantu Bapak TNI-AU Lanud Roesmin untuk membagikan Bantuan sosialnya kepada masyarakat dikelurahan Simpangtiga. Dampaknya pada masyarakat dapat terlihat dengan banyaknya antusias masyarakat dalam mengikuti KKn Balek Kampung ini, Diharapkan program pengabdian masyarakat sejenis dapat lebih digiatkan agar banyak masyarakat yang tadinya kurang informasi mengenai pandemi covid 19 ini menjadi lebih waspada pada aturan protokol kesehatan. Sinergi antara mahasiswa, akademisi dan pemerintah sangat diperlukan dengan demikian pandemi covid-19 ini akan segera berakhir.

\section{DAFTAR PUSTAKA}

Agustino, L. (2020). Analisis Kebijakan Penanganan Wabah Covid-19: Pengalaman Indonesia Analysis Of Covid-19 Outbreak Handling Policy: The Experience Of Indonesia. Junal Borneo Administrator, 16(2), 253-270.

Bahri, S., \& Arafah, N. (2020). Analisis Manajemen SDM dalam Mengembangkan Strategi Pembelajaran di Era New Normal. Tafkir: Interdisciplinary Journal of Islamic Education, 1(1), $20-40$.

Harirah, Z., \& Rizaldi, A. (2020). Merespon Nalar Kebijakan Negara Dalam Menangani Pandemi Covid 19 Di Indonesia. Jurnal Ekonomi Dan Kebijakan Publik Indonesia, 7(1), 36-53. https://doi.org/10.24815/ekapi.v7i1.17370

Herlan, Efriani, Sikwan, A., Hasanah, Bayuardi, G., Listiani, E. I., \& Yulianti. (2020). Keterlibatan Akademisi Dalam Menanggulangi Dampak Covid-19 Terhadap Masyarakat Melalui Aksi Berbagi Sembako. JCES (Journal of Character Education Society), 3(2), 267-277.

Laksono, B. A. (2018). The Community Empowerment Through Social and. Jurnal Pendidikan Humaniora, 6(3), 115-122.

Oktaviyani, D., Aprilia, D., Sari, R. U., Rohmah, S. N., \& Saputro, W. A. (2020). Pengaruh Otonomi Daerah Dalam Percepatan Penanganan Covid-19. Jurnal Manajemen Bisnis, 17(3), 415-424.

Pradana, A. A., Casman, C., \& Aini, N. (2020). Pengaruh Kebijakan Social Distancing pada Wabah Covid-19 Terhadap Kelompok Rentan di Indonesia. Jurnal Kebijakan Kesehatan Indonesia: JKKI, 09(02), 61-67.

Rahmi, V. A., Ismanto, H., \& Fathoni, M. Z. (2020). Inovatif Saat Pandemi Covid "Pelatihan Kewirausahaan Khas Perempuan Berbahan Sampah " Kolaborasi BUMDes ." DINAMISIA: Jurnal Pengabdian Kepada Masyarakat, 4(3), 418-425.

Sampurno, M. B. T., Kusumandyoko, T. C., \& Islam, M. A. (2020). Budaya Media Sosial, Edukasi Masyarakat, dan Pandemi COVID-19. SALAM: Jurnal Sosial Dan Budaya Syar-I, 7(5), 529-542. https://doi.org/10.15408/sjsbs.v7i5.15210

Saputra, C., \& Putra, I. D. (2020). Pemberdayaan Penanggulangan Covid-19 Bagi Petugas Kesehatan. JCES (Journal of Character Education Society), 3(2), 311-319.

Sunuantari, M. (2020). Sub TEMA: Covid-19, Komunikasi dan Community Empowerment Tata Kelola Black Zone Covid-19 Berbasis Komunitas (Vol. 17). Yogyakarta.

Telaumbanua, D. (2020). Urgensi Pembentukan Aturan Terkait Pencegahan Covid-19 di Indonesia. QALAMUNA: Jurnal Pendidikan, Sosial, Dan Agama, 12(01), 59-70. https://doi.org/10.37680/qalamuna.v12i01.290

Telaumbauna, D. (2020). Tinjauan Yuridis Penetapan Kedaruratan Kesehatan Masyarakat Akibat Covid-19. Jurnal Education and Development, 8(2), 30-36.

Walzer, N., \& Hamm, G. F. (2012). Community visioning programs: Processes and outcomes. Routledge. 